\title{
REGIONAL TSUNAMI HAZARD ASSESSMENT FOR COMMUNITIES ON THE KENAI PENINSULA, ALASKA
}

E.N. Suleimani, D.J. Nicolsky, J.B. Salisbury, and R.D. Koehler

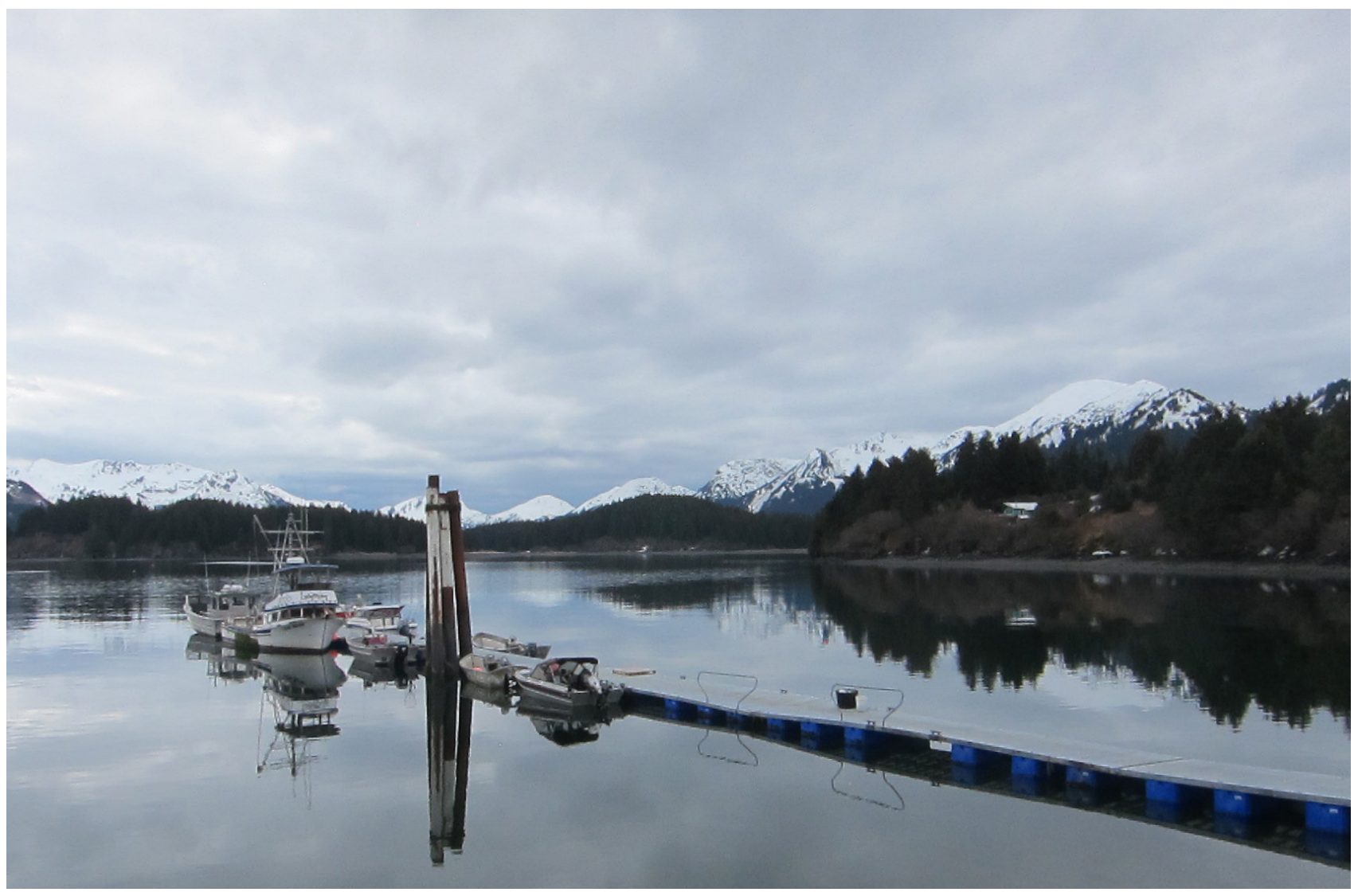

Port Graham, Alaska. Photo: Elena Suleimani.

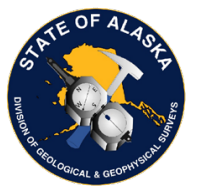





\section{REGIONAL TSUNAMI HAZARD ASSESSMENT FOR COMMUNITIES ON THE KENAI PENINSULA, ALASKA}

E.N. Suleimani, D.J. Nicolsky, J.B. Salisbury, and R.D. Koehler

Report of Investigation 2019-5

State of Alaska

Department of Natural Resources

Division of Geological \& Geophysical Surveys 
STATE OF ALASKA

Michael J. Dunleavy, Governor

\title{
DEPARTMENT OF NATURAL RESOURCES
}

Corri A. Feige, Commissioner

\section{DIVISION OF GEOLOGICAL \& GEOPHYSICAL SURVEYS}

\author{
Steve Masterman, State Geologist and Director
}

Publications produced by the Division of Geological \& Geophysical Surveys (DGGS) are available for free download from the DGGS website (dggs.alaska.gov). Publications on hard-copy or digital media can be examined or purchased in the Fairbanks office:

Alaska Division of Geological \& Geophysical Surveys 3354 College Rd., Fairbanks, Alaska 99709-3707

Phone: (907) 451-5010 Fax (907) 451-5050

dggspubs@alaska.gov|dggs.alaska.gov

DGGS publications are also available at:

Alaska State Library,

Historical Collections \& Talking Book Center

395 Whittier Street

Juneau, Alaska 99811

Alaska Resource Library and Information Services (ARLIS)

3150 C Street, Suite 100

Anchorage, Alaska 99503

Suggested citation:

Suleimani, E.N., Nicolsky, D.J., Salisbury, J.B., and Koehler, R.D., 2019, Regional tsunami hazard assessment for communities on the Kenai Peninsula, Alaska: Alaska Division of Geological \& Geophysical Surveys Report of Investigation 2019-5, 20 p., 3 sheets. doi.org/10.14509/30194
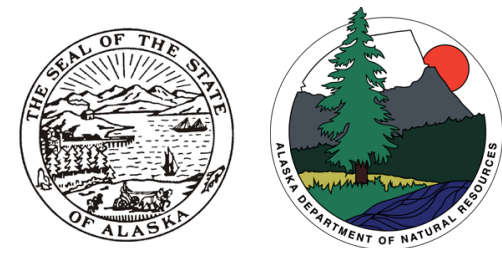


\section{Contents}

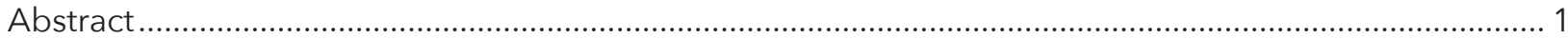

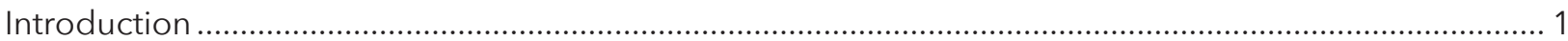

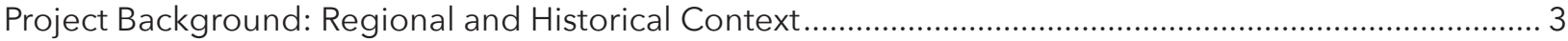

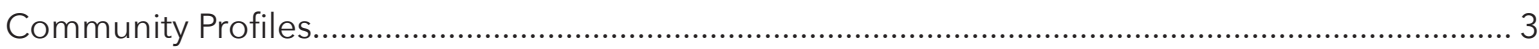

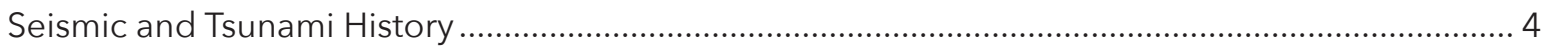

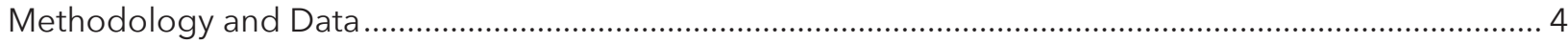

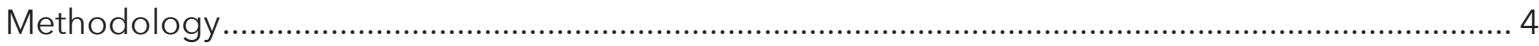

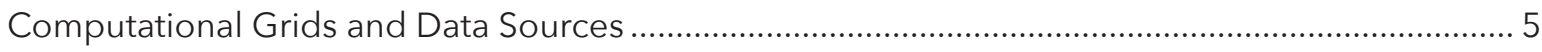

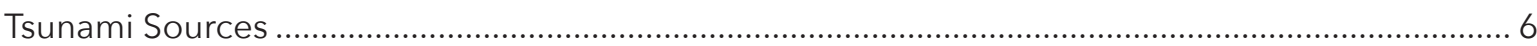

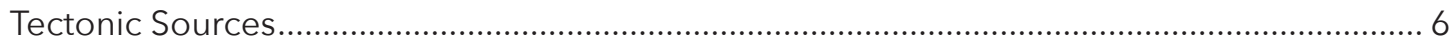

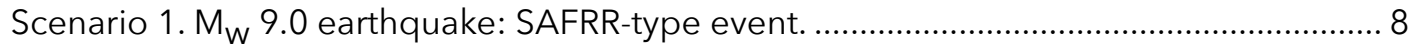

Scenario 2. $M_{w} 9.0$ earthquake: maximum slip at 15-25 km (9-15 mi) depth..................... 8

Scenario 3. $M_{w} 9.0$ earthquake: maximum slip at 25-35 km (15-21 mi) depth................... 8

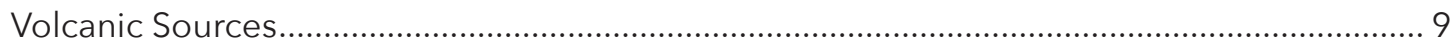

Scenario 4. East-directed mass flow from Augustine Volcano........................................... 10

Scenario 5. Northeast-directed mass flow from Augustine Volcano.................................... 10

Numerical Model of Tsunami Propagation and Runup.................................................................... 11

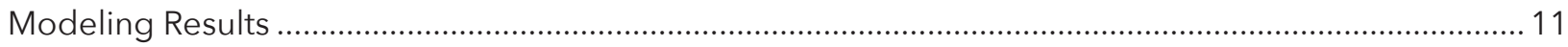

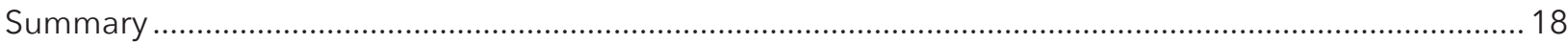

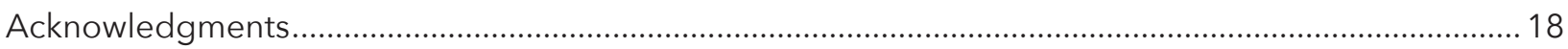

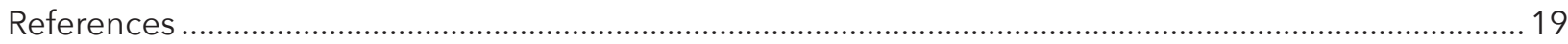

Figures

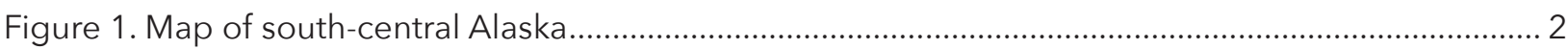

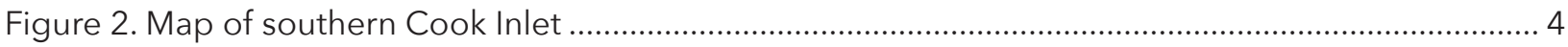

Figure 3. Nesting of the bathymetry/topography grids for numerical modeling of tsunami

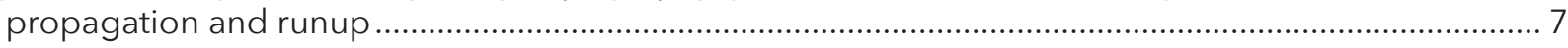

Figure 4. Vertical coseismic deformations corresponding to tectonic scenarios 1-3 ........................... 9

Figure 5. Initial tsunami wave heights for volcanic scenarios 4 and 5................................................. 10

Figure 6. Maximum tsunami height for scenarios 1-3 in the Kenai Peninsula level 3 grid ...................... 12

Figure 7. Maximum tsunami height for scenarios 4-5 in the Kenai Peninsula level 3 grid ...................... 13

Figure 8. Maximum composite tsunami height at Anchor Point............................................................. 14

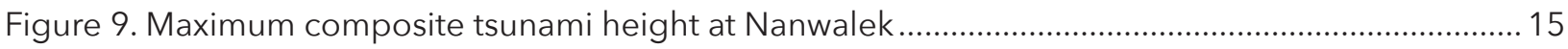

Figure 10. Maximum composite tsunami height at Port Graham .......................................................... 16

Figure 11. Time series of water level for scenarios 1-3 at Anchor Point, Nanwalek, and Port Graham ... 17

\section{Tables}

Table 1. Tsunami effects at the Kenai Peninsula communities.

Table 2. Nested grids used to compute propagation of tsunami waves generated in the Pacific

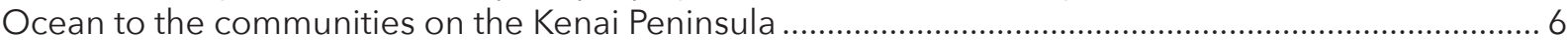

Table 3. Significant credible tectonic tsunami sources for the Kenai Peninsula communities .................. 10

Table 4. Summary of tsunami modeling results for the Kenai Peninsula communities............................. 11

\section{Map Sheets}

Sheet 1. Tsunami hazard map of Anchorage Point, Alaska

Sheet 2. Tsunami hazard map of Nanwalek, Alaska

Sheet 3. Tsunami hazard map of Port Graham, Alaska 



\title{
REGIONAL TSUNAMI HAZARD ASSESSMENT FOR COMMUNITIES ON THE KENAI PENINSULA, ALASKA
}

\author{
E.N. Suleimani, ${ }^{1}$ D.J. Nicolsky, ${ }^{1}$ J.B. Salisbury, ${ }^{2}$ and R.D. Koehler ${ }^{3}$
}

\begin{abstract}
We assess potential tsunami hazard for three coastal communities on the Kenai Peninsula, Alaska: Anchor Point, Nanwalek, and Port Graham. The primary tsunami hazard for these communities is considered to be near-field, with a major threat originating from tsunamigenic earthquakes along the Alaska-Aleutian megathrust. We numerically model tsunamis generated by three different megathrust earthquakes and two volcanic sources, analyze tsunami wave dynamics, and develop approximate tsunami hazard maps for the communities. The hypothetical tsunami scenarios that we examined simulate $M_{W} 9.0$ megathrust earthquakes with a slip distribution in the 5-35 km (3-22 mi) depth range along the Alaska-Aleutian megathrust, as well as tsunamigenic mass flows originating from Augustine Volcano. The maximum runup heights are $12.2 \mathrm{~m}(40 \mathrm{ft})$ in Anchor Point, $14 \mathrm{~m}(46 \mathrm{ft})$ in Nanwalek, and $14.9 \mathrm{~m}(49 \mathrm{ft})$ in Port Graham. Results presented here are intended to provide guidance to local emergency management agencies in initial tsunami inundation assessment, evacuation planning, and public education for mitigation of future tsunami hazards.
\end{abstract}

\section{INTRODUCTION}

Tsunami hazards along Alaska's Pacific coastline are high. Virtually all of Alaska's southern and southeastern coasts are defined by major offshore fault systems. Unlike tsunamis that are caused by distant earthquakes on the other side of the Pacific, Alaska's greatest tsunami hazards originate just offshore and can inundate coastlines within an hour of a causative earthquake. This reduces the time available to respond and evacuate, and can produce drastically higher wave heights than far-traveled tsunamis. Because many Alaska communities hug the shoreline (due to some combination of steep mountains, dense forests, and/or reliance on the open water for transportation), many Alaska communities are within the tsunami inundation zone and are at risk of rapid flooding. In addition to earthquake-generated (i.e., tectonic) tsunamis, mass movements of sediments down slopes (either on land or in the ocean) can also generate tsunamis. While rapid tsunami flooding is the immediate concern after a large coastal earthquake, dangerous near-shore ocean currents and permanent changes to the local coastline are additional concerns.

The local, tectonic tsunami danger to communities in south-central Alaska comes primarily from the Alaska-Aleutian subduction zone (fig. 1). This subduction zone marks the boundary between the Pacific plate to the south and the North American plate to the north. Relative to the North American plate, the Pacific Plate is moving northwest at approximately $5-8 \mathrm{~cm}$ (2-3 inches) per year, colliding with the North American plate and diving beneath it in a process known as subduction. The latest sequence of large megathrust earthquakes began in 1938 with a $M_{\mathrm{W}} 8.3$ earthquake west of Kodiak Island (Estabrook and others, 1994). Four subsequent events, the $1946 \mathrm{M}_{\mathrm{W}}$ 8.6 Aleutian (Lopez and Okal, 2006),

\footnotetext{
${ }^{1}$ Alaska Earthquake Center, Geophysical Institute, University of Alaska, P.O. Box 757320, Fairbanks, Alaska 99775-7320; ensuleimani@alaska.edu

${ }^{2}$ Alaska Division of Geological \& Geophysical Surveys, 3354 College Rd., Fairbanks, Alaska 99709-3707.

${ }^{3}$ Nevada Bureau of Mines and Geology, Mackay School of Earth Science and Engineering, University of Nevada, Reno, 1664 North Virginia Street, MS 178, Reno, NV 89557
} 


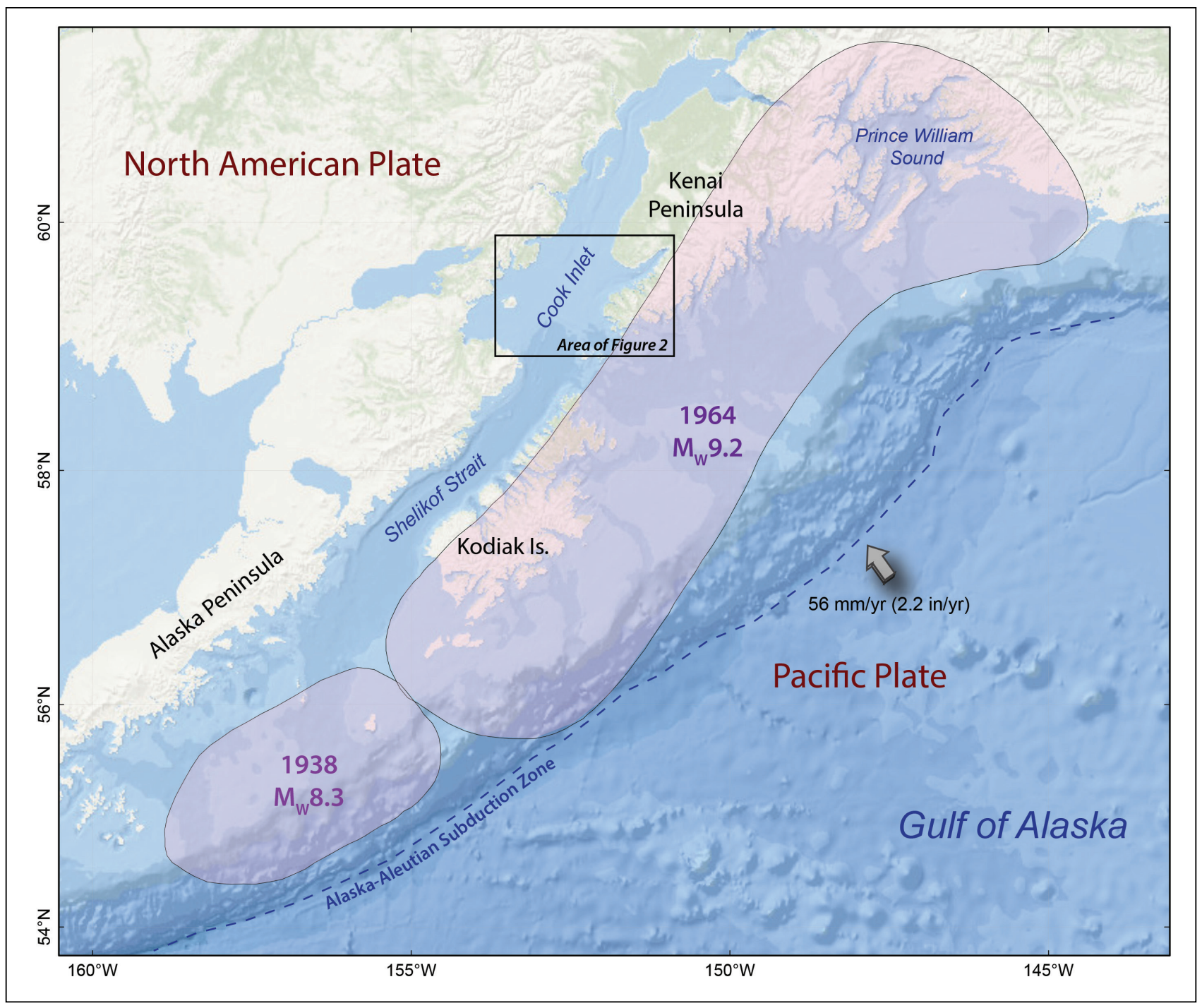

Figure 1. Map of south-central Alaska. The rupture areas of the 1938 and 1964 earthquakes are shown by pink-shaded polygons. Black rectangle outlines the area shown in figure 2.

$1957 \mathrm{M}_{\mathrm{W}}$ 8.6 Andreanof Islands (Johnson and others, 1994), $1964 \mathrm{M}_{\mathrm{w}} 9.2$ Alaska (Kanamori, 1970), and $1965 \mathrm{M}_{\mathrm{w}} 8.7$ Rat Island (Wu and Kanamori, 1973) earthquakes, ruptured almost the entire length of the megathrust. Tsunamis generated by these great earthquakes reached Alaska coastal communities within minutes and resulted in widespread damage and loss of life (National Centers for Environmental Information [NCEI; formerly known as National Geophysical Data Center] Global Historical Tsunami Database, doi.org/10.7289/V5PN93H7).

The specifics of tsunami hazards are particular to each community and vary considerably over large regions. The shape of the coastline, local bathymetry, and topography all affect tsunami impacts. More importantly, however, is the earthquake source (the location, size, and style) being considered and the community's location relative to that earthquake.

The impacts of future earthquakes and tsunamis can be reduced if citizens, emergency managers, and city planners take steps to mitigate the hazards. This report is intended to support hazard mitigation efforts by providing approximate tsunami hazard estimates for three Kenai Peninsula communities: Anchor Point, Nanwalek and Port Graham (fig. 2). The scenario earthquakes, numer- 
ical tsunami models, and resulting maps are developed on a regional level and lack the precision of studies that are fully tailored to individual communities (e.g., Nicolsky and others, 2013; Nicolsky and others, 2014; Suleimani and others, 2013, 2015). The current study does not include sensitivity tests and is based on three scenario earthquakes and two volcanic sources. Even so, the results provide a good first approximation of tsunami hazard. The maps, documentation, and available digital data provide a foundation for public education, support the development of evacuation procedures, and provide insights intended to improve community resilience.

\section{PROJECT BACKGROUND: REGIONAL AND HISTORICAL CONTEXT}

\section{Community Profiles}

The following information is paraphrased from the Alaska Community Database Online provided by the Alaska Department of Commerce, Community, and Economic Development, Division of Community and Regional Affairs (DCCED/DCRA, 2013).

Anchor Point (59 46'39”N, 151\%46'13”W), population 2,059, is located on the Kenai Peninsula at the junction of the Anchor River and its North Fork, 14 miles northwest of Homer at mile 156 of the Sterling Highway. In the summer of 1778, Captain James Cook and crews of the Resolution and Discovery sailed into Cook Inlet looking for the Northwest Passage and gave Anchor Point its name after losing a kedge anchor to the "awesome tidal currents." A post office was established in 1949, and the Sterling Highway provides access to Anchorage. The nearby community of Homer offers an airport, state ferry access, and docking and boat launching facilities.

Port Graham $\left(59^{\circ} 20^{\prime} 52^{\prime \prime} \mathrm{N}, \quad 151^{\circ} 50^{\prime} \mathrm{W}\right)$, population 168 , is at the southern end of the Kenai Peninsula on the shore of Port
Graham. It is adjacent to Nanwalek, 7.5 miles southwest of Seldovia, and 28 air miles from Homer. The earliest known settlers were Russians from the nearby trading post at Nanwalek. In 1850, the RussianAmerican Company established a coal mine at Port Graham, but it was not economical and lasted only a few years. Port Graham became the site of a cannery and wharf, according to the U.S. Geological Survey, in 1909. In 1911, the Fidalgo Island Packing Company established a cannery, and Aleuts from Nanwalek moved to the community. A post office operated between 1938 and 1961. The cannery burned in 1960 . It was rebuilt in 1968 by Whitney/Fidalgo and was sold to the village corporation in 1983 . A pink salmon hatchery began operations in 1991. In January 1998, the hatchery and salmon processing plant were destroyed by fire. The hatchery and processing plant were rebuilt and re-opened in June 1999. The cannery continues to be the main economic activity in the community, employing residents of Nanwalek as well. Port Graham is a traditional Alutiiq village with a fishing and subsistence lifestyle.

Nanwalek $\left(59^{\circ} 21^{\prime} 13^{\prime \prime} \mathrm{N}, 151^{\circ} 54^{\prime} 45^{\prime \prime} \mathrm{W}\right)$, formerly English Bay, population 275, is located at the southern tip of the Kenai Peninsula, southwest of Seldovia and east of Port Graham. The village of Nanwalek was originally the site of a Russian trading post called Alexandrovsk. A Russian Orthodox church was built in the community in 1870. In 1930, a replacement church was constructed, and it is a designated national historic site. In 1991, locals changed the community name from English Bay to Nanwalek, meaning "place by lagoon." Many of the current residents are of mixed Russian and Sugpiaq (Alutiiq) lineage. Villagers speak Sugtestun, a dialect of Eskimo similar to Yup'ik. Nanwalek is a traditional Alutiiq village. Subsistence activities are a large part of the culture. 


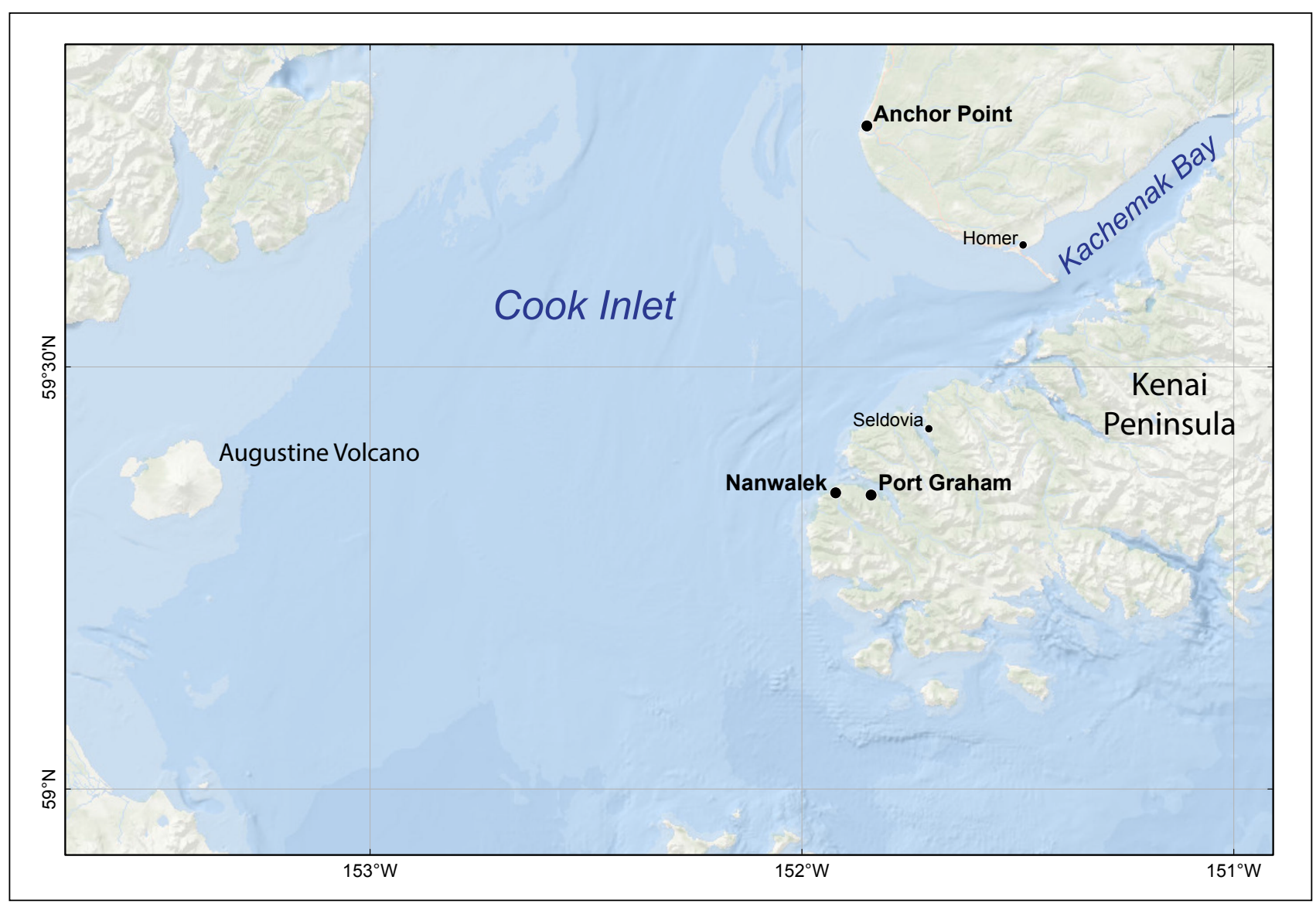

Figure 2. Map of southern Cook Inlet, showing locations of coastal communities considered in this report.

\section{Seismic and Tsunami History}

The rate of plate convergence near the Kenai Peninsula is approximately $56 \mathrm{~mm}$ (2.2 in) per year (DeMets and others, 1990). The eastern end of the megathrust has produced significant tsunamigenic earthquakes in the past. On March 27, 1964, south-central Alaska was struck by the largest earthquake ever recorded in North America. This $\mathrm{M}_{\mathrm{W}} 9.2$ megathrust earthquake (fig. 1) generated a destructive tsunami that caused fatalities and great damage in Alaska, Hawaii, and the west coast of the United States and Canada. The earthquake ruptured an 800-km-long (-500-mi-long) section of the Alaska-Aleutian megathrust, producing vertical displacements over an area of about $285,000 \mathrm{~km}^{2}\left(110,039 \mathrm{mi}^{2}\right)$ in south-central Alaska (Plafker, 1969). The area of coseismic subsidence included Kodiak Island, Kenai Peninsula, Cook Inlet, and part of northern Prince William Sound (fig. 1). The major zone of uplift was seaward of the subsidence zone, in Prince William Sound and the Gulf of Alaska (Plafker, 1969). Of the 131 fatalities associated with this earthquake, 122 were caused by tsunamis (Lander, 1996).

According to Lander (1996) and the Global Historical Tsunami Database of the National Centers for Environmental Information (NCEI), National Oceanic \& Atmospheric Administration (NOAA) (doi.org/10.7289/V5PN93H7), Port Graham and Nanwalek have been affected by historical tsunamis (table 1).

\section{METHODOLOGY AND DATA Methodology}

The regional tsunami hazard maps presented here are the product of collaborative efforts between state and federal agencies to assist coastal communities in Alaska with tsunami hazard assess- 
Table 1. Tsunami effects at the Kenai Peninsula communities. Data from the National Centers for Environmental Information (NCEl; formerly known as National Geophysical Data Center [NGDC]) Global Historical Tsunami Database (doi.org/10.7289/N5PN93H7) and comments from Lander (1996).

\begin{tabular}{|c|c|c|c|c|}
\hline Date & Magnitude (MW) & Origin & $\begin{array}{l}\text { Maximum water } \\
\text { height }(\mathrm{m})\end{array}$ & Comments \\
\hline \multicolumn{5}{|c|}{ Port Graham } \\
\hline $10 / 06 / 1883$ & Volcano & Cook Inlet & 9.1 & $\begin{array}{l}\text { Flooded homes and scattered } \\
\text { boats }\end{array}$ \\
\hline 03/28/1964 & 9.2 & Gulf of Alaska & 3.0 & \\
\hline \multicolumn{5}{|c|}{ Nanwalek } \\
\hline 10/06/1883 & Volcano & Cook Inlet & 6 & $\begin{array}{l}\text { The daily log of the Alaska } \\
\text { Commercial Company trading } \\
\text { post in English Bay recorded } \\
\text { the arrival of } 4 \text { waves during the } \\
\text { eruption of Augustine Volcano. }\end{array}$ \\
\hline
\end{tabular}

ment. In recent years, similar tsunami hazard studies have been published for other communities (Nicolsky and others, 2011a; Nicolsky and others, 2013; Nicolsky and others, 2014; Suleimani and others, 2010; Suleimani and others, 2013, 2015). Because the currently available digital elevation models (DEMs) for these southern Alaska communities are of insufficient quality for high-resolution modeling, we follow the National Tsunami Hazard Mitigation Program (NTHMP, 2010) guidelines (nws.weather.gov/nthmp/publications.html) for determining tsunami hazard zones for areas that have either low risk due to small population size and minimal infrastructure vulnerability, or do not have access to high-resolution tsunami inundation maps. The tsunami hazard maps of the three Kenai Peninsula communities are developed using the methodology described in detail in Suleimani and others (2018). In short, for the three scenario earthquakes and two volcanic scenarios, we modeled water dynamics from source to community and computed maximum tsunami wave heights using the highest resolution grids available (see table 2 ). Each model run covers 3 hours of post-earthquake tsunami propagation to account for all waves in the wave train, as well as secondary (reflected) wave interactions. At every location throughout the high-resolution grids, the maximum tsunami height from any of the five scenarios is saved, and we use these maximum values to generate a new, "composite" map of maximum wave heights that can be expected from the earthquake scenarios.

\section{Computational Grids and Data Sources}

To develop a regional tsunami hazard map we use a series of nested computational grids. A nested grid allows for higher resolution in areas where it is needed without expending computer resources in areas where it is not. The bathymetric and topographic relief in each nested grid is based on DEMs developed at the NCEI. The extent of each grid used in this mapping project is shown in figure 3 and listed in table 2 . The coarsest grid, with 2-arc-minute (approximately $2 \mathrm{~km}$ [1.2 mi]) resolution, spans the central and northern Pacific Ocean. The bathymetric data for the 2-arc-minute-resolution grid is extracted from the ETOPO2 dataset (NGDC, 2006, doi.org/10.7289/V5J1012Q). We use two intermediate grids between the coarsestand highest-resolution grids (table 2). The first intermediate grid of 24 arc-second resolution (level 1) was developed to accommodate the current tsunami mapping project for the Kenai Peninsula as well as other tsunami mapping efforts for communities located on Kodiak Island and around 
Table 2. Nested grids used to compute propagation of tsunami waves generated in the Pacific Ocean to the communities on the Kenai Peninsula. The fine-resolution grid is used to compute the inundation. Note that the grid resolution in meters is not uniform and is used to illustrate grid fineness in the Cook Inlet region. The first dimension is the longitudinal grid resolution; the second is the latitudinal resolution.

\begin{tabular}{|c|c|c|c|c|}
\hline \multirow[b]{2}{*}{ Grid name } & \multicolumn{2}{|c|}{ Resolution } & \multirow{2}{*}{$\begin{array}{l}\text { West-East } \\
\text { boundaries }\end{array}$} & \multirow{2}{*}{$\begin{array}{l}\text { South-North } \\
\text { boundaries }\end{array}$} \\
\hline & Arc-seconds & $\begin{array}{l}\text { Meters (near } \\
\text { Anchor Point) }\end{array}$ & & \\
\hline Level 0, Northern Pacific & $120 \times 120$ & $\approx 2,015 \times 3,700$ & $\begin{array}{l}120^{\circ} 00^{\prime} \mathrm{E}- \\
100^{\circ} 00^{\prime} \mathrm{W}\end{array}$ & $\begin{array}{l}10^{\circ} 00^{\prime} \mathrm{N}- \\
65^{\circ} 00^{\prime} \mathrm{N}\end{array}$ \\
\hline Level 1, South-central Alaska & $24 \times 24$ & $\approx 403 \times 740$ & $\begin{array}{l}156^{\circ} 00^{\prime} \mathrm{W}- \\
145^{\circ} 00^{\prime} \mathrm{W}\end{array}$ & $\begin{array}{l}55^{\circ} 00^{\prime} \mathrm{N}- \\
62^{\circ} 00^{\prime} \mathrm{N}\end{array}$ \\
\hline $\begin{array}{l}\text { Level 2, Coarse resolution, Augustine } \\
\text { Island }\end{array}$ & $8 \times 8$ & $\approx 135 \times 247$ & $\begin{array}{l}154^{\circ} 18^{\prime} 10^{\prime \prime} \mathrm{W}- \\
152^{\circ} 52^{\prime} 09^{\prime \prime} \mathrm{W}\end{array}$ & $\begin{array}{l}58^{\circ} 56^{\prime} 28^{\prime \prime} \mathrm{N}- \\
59^{\circ} 48^{\prime} 01^{\prime \prime} \mathrm{N}\end{array}$ \\
\hline $\begin{array}{l}\text { Level 2, Coarse resolution, Kenai } \\
\text { Peninsula }\end{array}$ & $8 \times 8$ & $\approx 135 \times 247$ & $\begin{array}{l}152^{\circ} 27^{\prime} 46^{\prime \prime} \mathrm{W}- \\
150^{\circ} 09^{\prime} 20^{\prime \prime} \mathrm{W}\end{array}$ & $\begin{array}{l}58^{\circ} 48^{\prime} 27^{\prime \prime} \mathrm{N}- \\
60^{\circ} 00^{\prime} 34^{\prime \prime} \mathrm{N}\end{array}$ \\
\hline $\begin{array}{l}\text { Level 3, Fine resolution, Augustine } \\
\text { Island }\end{array}$ & $8 / 3 \times 8 / 3$ & $\approx 45 \times 82$ & $\begin{array}{l}153^{\circ} 39^{\prime} 37^{\prime \prime} \mathrm{W}- \\
153^{\circ} 05^{\prime} 10^{\prime \prime} \mathrm{W}\end{array}$ & $\begin{array}{l}59^{\circ} 11^{\prime} 43^{\prime \prime} \mathrm{N}- \\
59^{\circ} 30^{\prime} 27^{\prime \prime} \mathrm{N}\end{array}$ \\
\hline Level 3, Fine resolution, Kenai Peninsula & $8 / 3 \times 8 / 3$ & $\approx 45 \times 82$ & $\begin{array}{l}152^{\circ} 09^{\prime} 08^{\prime \prime} \mathrm{W}- \\
150^{\circ} 51^{\prime} 41^{\prime \prime} \mathrm{W}\end{array}$ & $\begin{array}{l}59^{\circ} 04^{\prime} 16^{\prime \prime} \mathrm{N}- \\
59^{\circ} 52^{\prime} 14^{\prime \prime} \mathrm{N}\end{array}$ \\
\hline
\end{tabular}

Prince William Sound. The data sources and methodology used to develop the 24-arc-second DEMs are described in detail by Lim and others (2011). The 8- and 8/3-arc-second DEMs were developed by the NCEI in the scope of NTHMP by resampling datasets used to produce the southern Alaska 24-arc-second coastal relief model and the Kachemak Bay 1-arc-second DEM at the appropriate resolution (Jason Caldwell, oral comm.).

The spatial resolution of the fine-resolution grid cells, about $45 \times 82 \mathrm{~m}(147 \times 269 \mathrm{ft})$, satisfies NOAA's minimum recommended requirements for estimation of the tsunami hazard zone (NTHMP, 2010); however, no DEM verification efforts were conducted to reduce uncertainties in the high-resolution (level 3) grid of the Kenai Peninsula. Therefore, in this report we do not perform high-resolution runup modeling, but provide an estimation of the tsunami hazard zone by extrapolating the maximum composite tsunami wave height on land according to the tsunami scenarios described below. We account for uncertainties inherent to this method by applying a safety factor of 1.3 to the estimated hazard zone.

\section{Tsunami Sources Tectonic Sources}

In this project we use a deterministic approach to develop potential tsunami sources, which is distinctly different from the probabilistic tsunami hazard analyses used in projects with different objectives, such as land-use planning or insurance estimates (Geist and Parsons, 2006). Alaska tsunami hazard maps are produced on the basis of significant credible tsunami scenarios for a given segment of the coastline. Although we do not explicitly develop worst-case credible tsunami scenarios for the Kenai Peninsula, we use the same underlying assumptions and results regarding the maximum considered earthquake scenarios for other locations along the Alaska-Aleutian subduction zone.

In this regional tsunami hazard assessment we consider three characteristic tsunamigenic earthquake scenarios (e.g., Suleimani and others, 2018) 


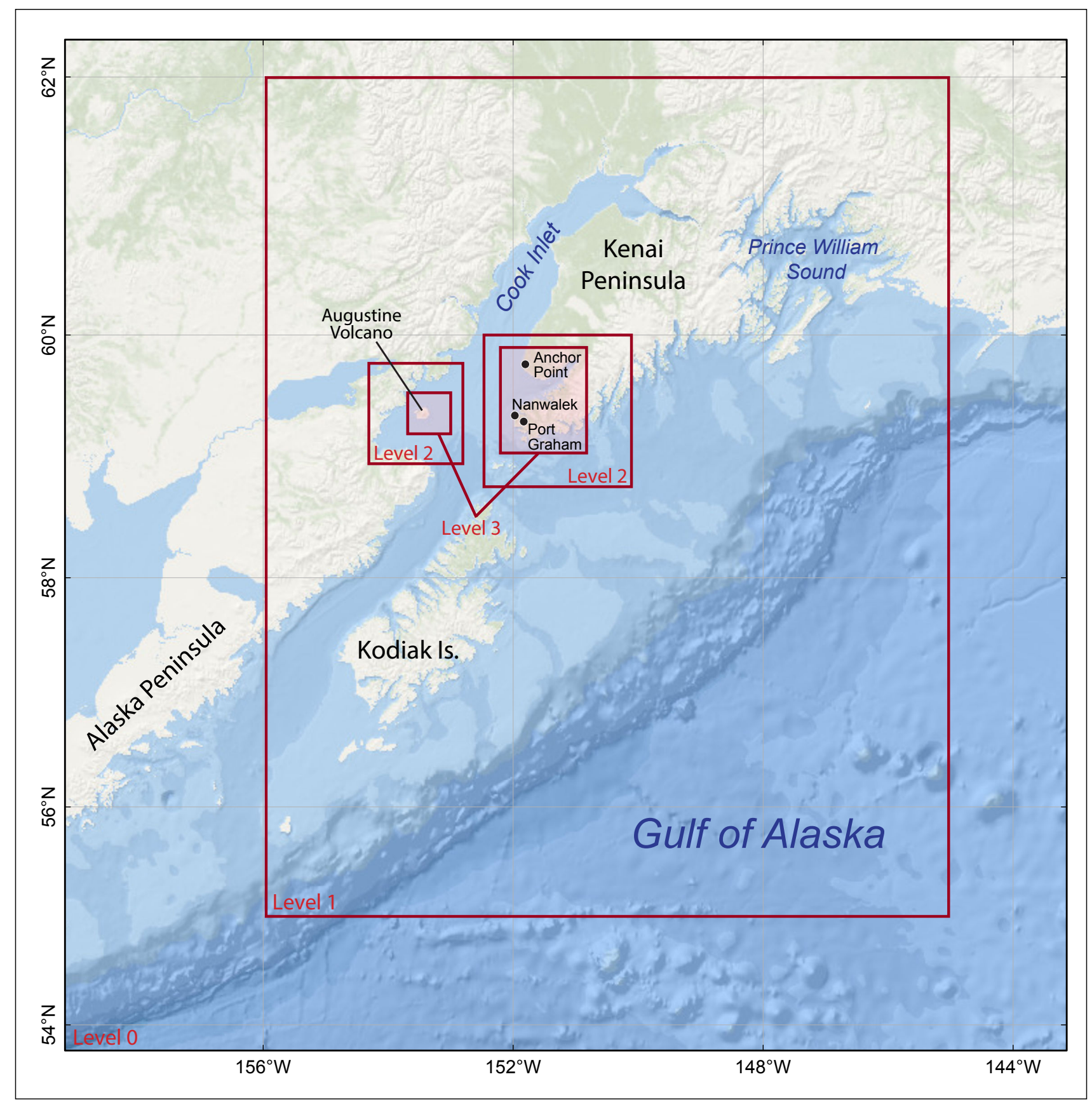

Figure 3. Nesting of the bathymetry/topography grids for numerical modeling of tsunami propagation and runup. The coarsest grid, level 0, covers the central and northern Pacific Ocean. The location of each embedded grid is marked by a red rectangle. Refer to table 2 for grid parameters.

and two volcano-generated tsunamis. The potential megathrust ruptures have a uniform slip distribution along strike, but differ in the downdip slip distribution pattern such that the depth range at which the maximum slip occurs varies from the shallow region close to the trench to the deeper parts of the plate interface. All ruptures have the same lateral extent, which is determined by the location of 
communities and constrained by maximum seismic moment. Refer to Suleimani and others (2018) for a description of the scenario development and for the proposed slip distributions.

The five tsunami scenarios for the Kenai Peninsula communities are outlined below. The vertical coseismic deformations for scenarios 1, 2, and 3 are shown in figure 4, and the initial tsunami wave heights corresponding to scenarios 4 and 5 are presented in figure 5 . The main rupture parameters are listed in table 3, and the amount of permanent subsidence for each community is given in table 4 .

\author{
Scenario 1. $M_{W} 9.0$ \\ earthquake: SAFRR-type \\ event.
}

Scenario 2. $\mathrm{M}_{\mathrm{W}} 9.0$ earthquake: maximum slip at 15-25 km (9-15 mi) depth.

Scenario 3. $M_{W} 9.0$ earthquake: maximum slip at 25-35 km (15-21 mi) depth.
A hypothetical $\mathrm{M}_{\mathrm{W}} 9.0$ earthquake rupturing the AlaskaAleutian megathrust. During the 2011 Tohoku, Japan, earthquake a large amount of slip occurred between the subducting and overriding plates near the Japan trench (Fujii and others, 2011; Shao and others, 2011). The USGS Science Application for Risk Reduction (SAFRR) project, in collaboration with NOAA and State of California agencies, has developed a plausible hypothetical tsunami scenario (Kirby and others, 2013) to describe the impacts of a tsunami generated by an earthquake in the Alaska Peninsula region (Ross and others, 2013). Here we assume that the slip distribution in the downdip direction is the same as that in the SAFRR source, where greater slip occurs closer to the trench. The slip is distributed almost uniformly along strike except for the edges of the rupture, where it tapers. The maximum slip of $46 \mathrm{~m}(151 \mathrm{ft})$ is at a depth of 5-15 km (3-9 mi). Vertical coseismic deformations for this scenario are shown in figure $4 \mathrm{~A}$.

A hypothetical $M_{w} 9.0$ earthquake rupturing the AlaskaAleutian megathrust. The slip is distributed almost uniformly along strike, except for the edges of the rupture, where it tapers. The maximum slip of $35 \mathrm{~m}(115 \mathrm{ft})$ is at a depth of 15-25 km (9-15 mi). Vertical coseismic deformations for this scenario are shown in figure $4 \mathrm{~B}$.

A hypothetical $M_{\mathrm{W}} 9.0$ earthquake rupturing the AlaskaAleutian megathrust. The slip is distributed almost uniformly along strike except for the edges of the rupture, where it tapers. The maximum slip of $35 \mathrm{~m}(115 \mathrm{ft})$ is at a depth of 25-35 km (15-22 mi). Vertical coseismic deformations for this scenario are shown in figure $4 \mathrm{C}$. 


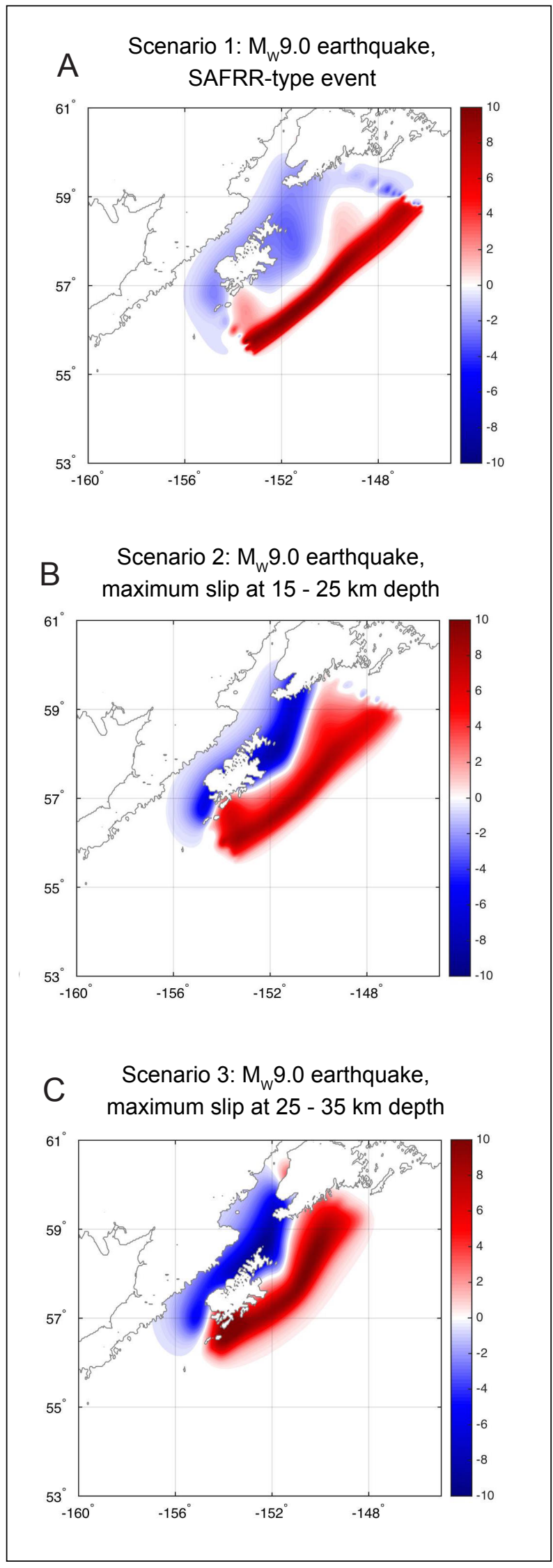

\section{Volcanic Sources}

In addition to tectonic tsunamis, we consider tsunami waves that could be generated by volcanic mass flows from Augustine Volcano, located on the west side of Cook Inlet (fig. 2). Augustine Volcano is the most historically active volcano in this region, and in the past several million years has produced numerous debris avalanches that reached the sea. Deposits of these debris avalanches are present along all flanks of Augustine Volcano (Begét and Kienle, 1992; Waitt and others, 1996). The 1883 eruption resulted in a large debris avalanche that left deposits at Burr Point along the north coast of Augustine Island (fig. 5). The sudden displacement of sea water from the impact of the 1883 debris avalanche apparently triggered a tsunami that was recorded at the village of Alexandrovsk, now Nanwalek (Kienle and others, 1987). Waythomas and others (2006) developed a model of a gravity-driven subaerial mass flow to evaluate the Burr Point debris avalanche and its motion down Augustine Volcano to the shoreline, where it entered the water. They estimated the volume of the Burr Point avalanche deposit at about 8.8 $\mathrm{x} 10^{7} \mathrm{~m}^{3}$, and the width at the shoreline at about $5 \mathrm{~km}$. We use parameters derived by Waythomas and others (2006) for initial tsunami amplitude and wavelength to make two hypothetical tsunami sources that enter the sea from the eastern and the northeastern flanks of the volcano. Each of these hypothetical debris flows has a volume of $1.25 \mathrm{x}$ $10^{8} \mathrm{~m}^{3}$, and the maximum initial wave height they produce is 20 meters. Wave heights are limited by the shallow water depth around Augustine Island within the run-out zone of typical Augustine debris avalanches (Waythomas and others, 2006).

Figure 4. Vertical coseismic deformations corresponding to tectonic scenarios 1-3. Blue areas are associated with coseismic ground subsidence; areas of uplift are shown in red. 
Scenario 4. East-directed mass flow from Augustine

Volcano.
A hypothetical mass flow from the eastern flank of Augustine Volcano. The initial displacement of the sea surface for this scenario is shown in figure $5 \mathrm{~A}$.
Scenario 5. Northeastdirected mass flow from Augustine Volcano.
A hypothetical mass flow from the north-eastern flank of Augustine Volcano. The initial displacement of the sea surface for this scenario is shown in figure 5B.
A

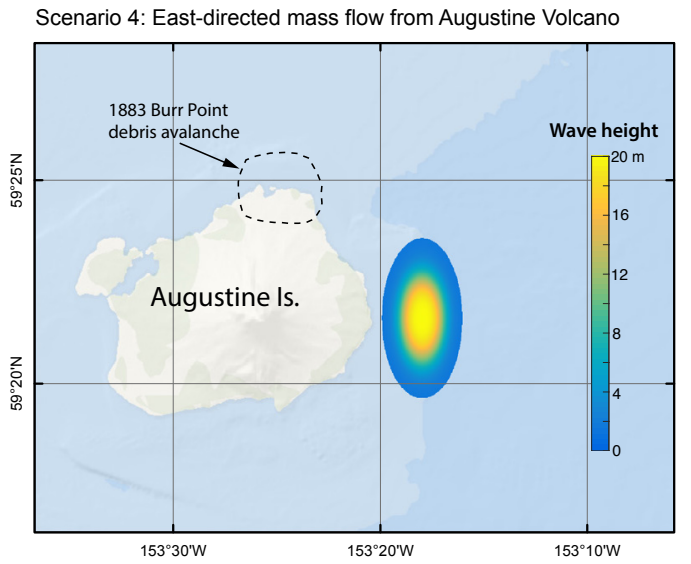

B

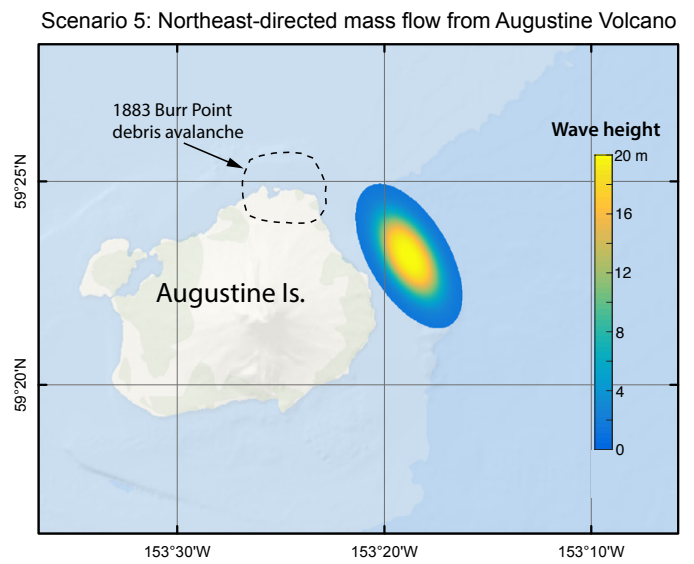

Figure 5. Initial tsunami wave heights for volcanic scenarios 4 and 5, the east- and northeast-directed mass flows from Augustine Volcano.

Table 3. Significant credible tectonic tsunami sources for the Kenai Peninsula communities.

\begin{tabular}{|c|c|c|c|c|c|c|}
\hline & Scenarios & $\begin{array}{c}\text { Depth range, } \\
\text { km (mi) }\end{array}$ & $\begin{array}{l}\text { Maximum slip } \\
\text { depth range, } \\
\text { km (mi) }\end{array}$ & $\begin{array}{l}\text { Maximum slip, } \\
\mathrm{m}(\mathrm{ft})\end{array}$ & $\begin{array}{l}\text { Maximum } \\
\text { regional } \\
\text { subsidence, } \\
\mathrm{m}(\mathrm{ft})\end{array}$ & $\begin{array}{l}\text { Maximum } \\
\text { regional uplift, } \\
\mathrm{m}(\mathrm{ft})\end{array}$ \\
\hline 1 & $\begin{array}{l}M_{w} 9.0 \\
\text { earthquake: } \\
\text { SAFRR-type event, } \\
\text { slip near the } \\
\text { trench }\end{array}$ & $8-54(5-33)$ & $11-14(7-8.5)$ & $55-65(180-213)$ & $-3.6(-11.8)$ & $10.6(34.8)$ \\
\hline 2 & $\begin{array}{l}M_{W} 9.0 \\
\text { earthquake: } \\
\text { Maximum slip at } \\
15-25 \mathrm{~km} \text { ( } 9.3- \\
15.5 \text { mi) depth }\end{array}$ & $5-35(3-21.7)$ & $15-25(9.3-15.5)$ & $34-35(111-115)$ & $-8.6(-28.2)$ & $8.9(29.2)$ \\
\hline 3 & $\begin{array}{l}M_{w} 9.0 \\
\text { earthquake: } \\
\text { Maximum slip at } \\
25-35 \mathrm{~km} \text { (15.5- } \\
21.7 \mathrm{mi}) \text { depth }\end{array}$ & $14-45(8-26)$ & $25-35(15.5-21.7)$ & $34-35(111-115)$ & $-9.6(-31.5)$ & $12.0(39.4)$ \\
\hline
\end{tabular}


Table 4. Summary of tsunami modeling results for the Kenai Peninsula communities. "Actual subsidence" is the subsidence that the model shows for the community, which may be (significantly) less than the maximum expected subsidence across the entire region for that same earthquake scenario. Maximum assumed runup height is the maximum composed tsunami height multiplied by the safety factor of 1.3 .

\begin{tabular}{|l|l|l|l|l|l|l|}
\hline Community & $\begin{array}{c}\text { Maximum } \\
\text { composite } \\
\text { tsunami } \\
\text { height, } \mathrm{m}(\mathrm{ft})\end{array}$ & $\begin{array}{c}\text { Maximum } \\
\text { assumed } \\
\text { runup height, } \\
\mathbf{m}(\mathrm{ft})\end{array}$ & $\begin{array}{c}\text { Actual } \\
\text { subsidence in } \\
\text { communities, } \\
\mathbf{m}(\mathrm{ft})\end{array}$ & $\begin{array}{c}\text { Composite } \\
\text { tsunami } \\
\text { height }\end{array}$ & $\begin{array}{c}\text { Tsunami } \\
\text { hazard map }\end{array}$ & \multicolumn{1}{c|}{$\begin{array}{c}\text { Calculated } \\
\text { time series }\end{array}$} \\
\hline Anchor Point & $9.4(30.8)$ & $12.2(40)$ & $-4.6(-15.0)$ & Figure 8 & Map sheet 1 & Figure 11A \\
\hline Nanwalek & $10.8(35.4)$ & $14(46)$ & $-7.3(-23.9)$ & Figure 9 & Map sheet 2 & Figure 11B \\
\hline Port Graham & $11.5(37.7)$ & $14.9(49)$ & $-7.2(-23.6)$ & Figure 10 & Map sheet 3 & Figure 11C \\
\hline
\end{tabular}

\section{Numerical Model of Tsunami Propagation and Runup}

The numerical model currently used by the Alaska Earthquake Center (AEC) for tsunami inundation mapping is a nonlinear, flux-formulated, shallow-water model (Nicolsky and others, 2011b) that has been validated (NTHMP, 2012) through a set of analytical benchmarks and tested against laboratory and field data (Synolakis and others, 2007). The application of the model to tsunami inundation mapping of Alaska coastal communities, including its assumptions and limitations, is described in a number of previous tsunami reports (for example, Suleimani and others, 2010, 2013, 2015; Nicolsky and others, 2011a, 2013, 2014). In this study, we conduct all model runs using bathymetric data that correspond to the Mean Higher High Water (MHHW) tide level in the Kenai Peninsula communities.

For each tsunami scenario, we first calculate the maximum tsunami wave heights in the highest-resolution grid over the course of the entire model run in the following way: at each grid point, the tsunami wave height is computed at every time step during the tsunami propagation time, and the maximum value is kept. Then we compute the composite maximum wave height from all considered scenarios by again choosing the maximum value for each grid point among all scenarios, and plot the results.

\section{MODELING RESULTS}

Figure 6 shows the maximum tsunami heights for scenarios $1-3$ in the Kenai Peninsula level 3 grid. For the modeled tectonic sources, scenario 1 produces the smallest amplitudes in Kachemak Bay and Cook Inlet, and scenario 3 generates the largest waves in all communities. The volcanic sources result in much smaller waves compared to the tectonic tsunamis (fig. 7). The northeastern volcanic source produces slightly larger waves in the communities, probably due to deeper water along the wave propagation path.

Figures 8-10 show maps of the maximum composite tsunami height for all scenarios, calculated in the vicinity of each community.

Map sheets 1-3 illustrate approximate tsunami hazards for the Kenai Peninsula communities, and table 4 summarizes all modeling results and provides the absolute maximum value of the tsunami height for each community (second column). This value, multiplied by a safety factor of 1.3, gives the value of the maximum estimated runup height (third column). For each community, we draw an elevation contour on the topographic map that corresponds to the maximum estimated runup height. This contour is the approximate boundary of the tsunami hazard zone, and should be used by emergency planners and public officials as a guideline in tsunami mitigation activities. For the communities of Port Graham and Nanwalek, we 


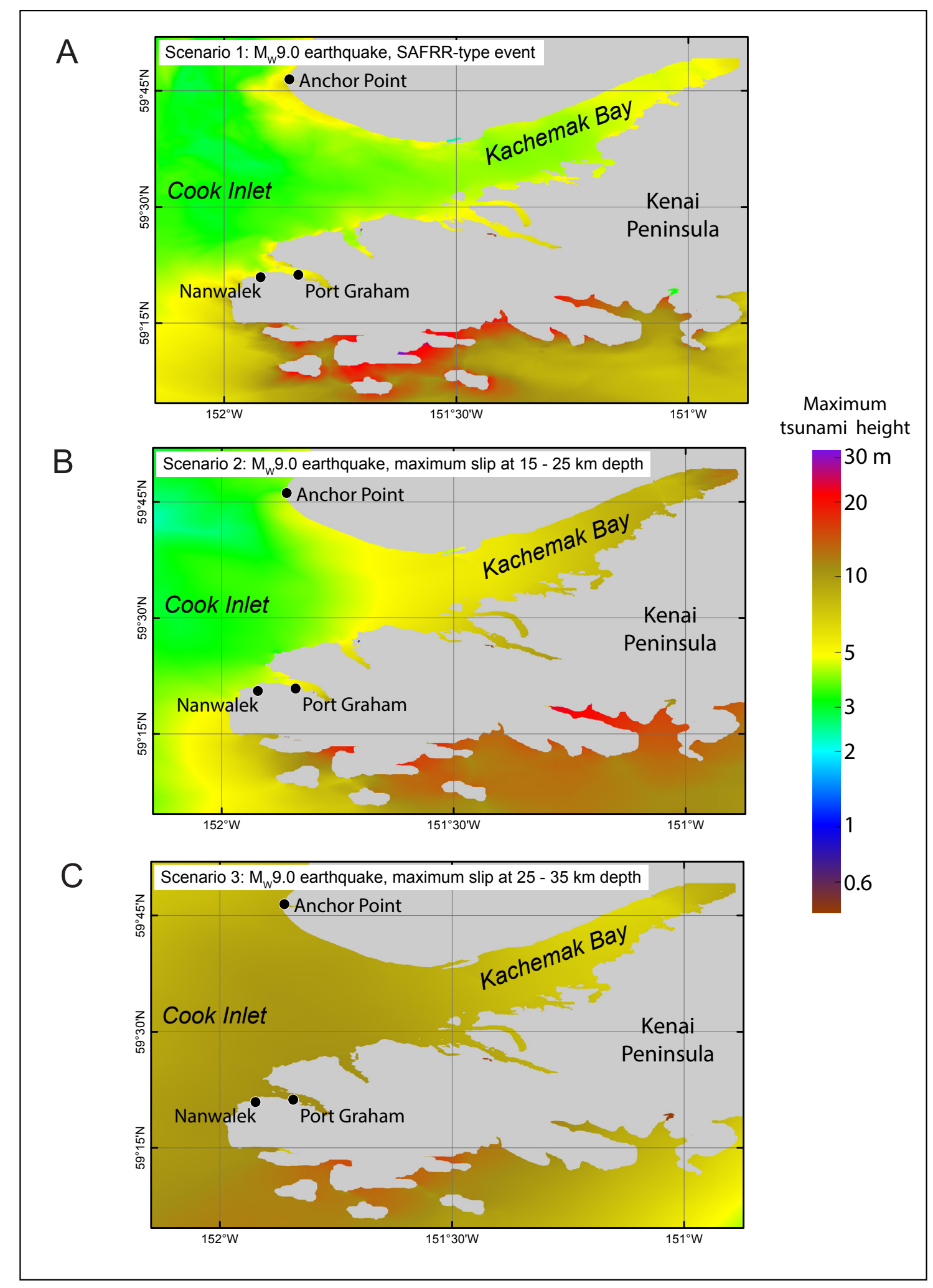

Figure 6. Maximum tsunami heights for scenarios 1-3 in the Kenai Peninsula level 3 grid. 


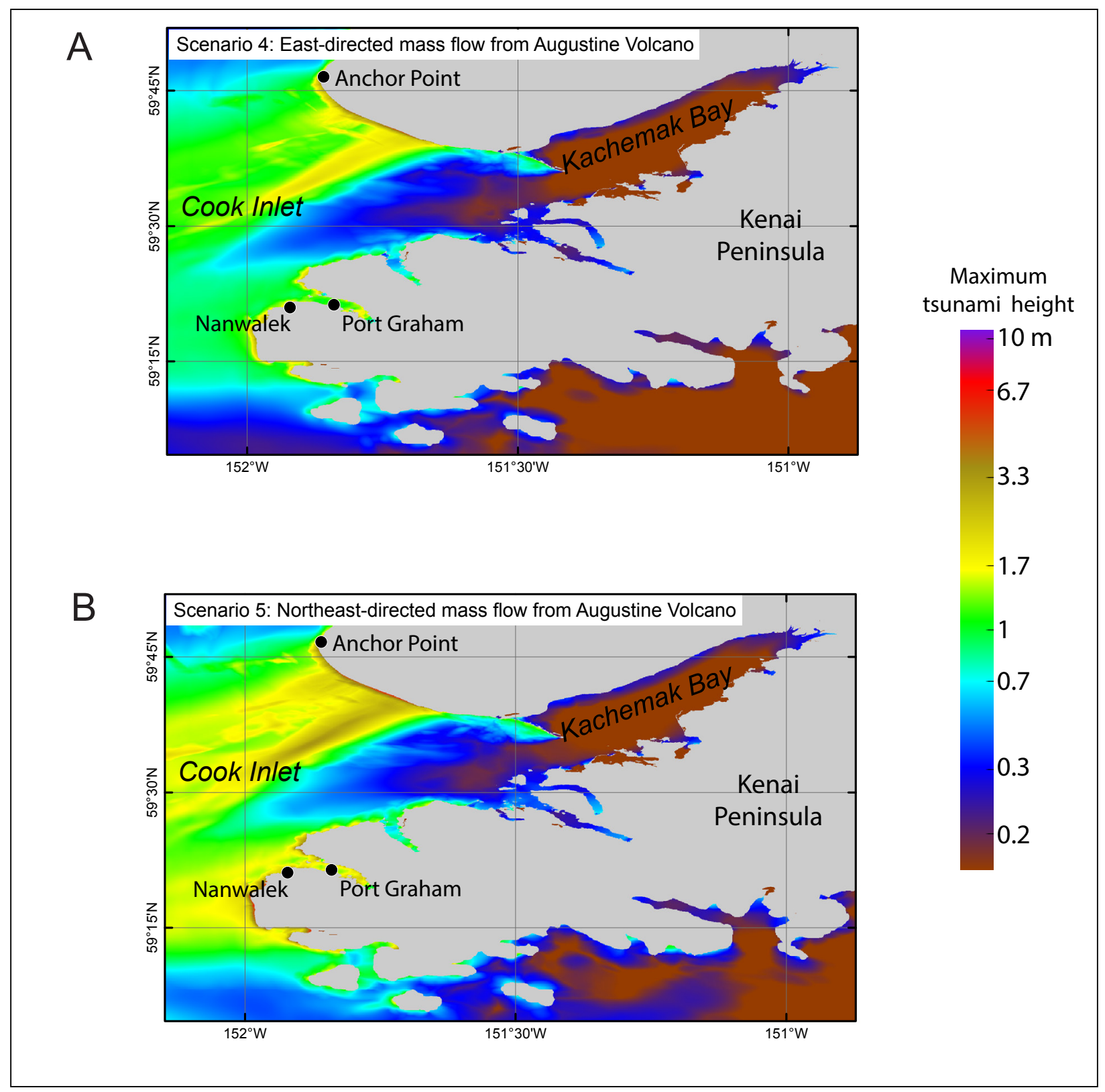

Figure 7. Maximum tsunami heights for scenarios 4-5 in the Kenai Peninsula level 3 grid.

used the DCRA elevation datasets and referenced the DCRA elevation contours to the MHHW datum (Macpherson and others, 2014). For both communities, we selected the closest contour to the estimated maximum wave height and extracted it as the tsunami hazard boundary. The $14.9 \mathrm{~m}$ $(49 \mathrm{ft})$ contour was extracted from the DCRA data for Port Graham, and the $14 \mathrm{~m} \mathrm{(46} \mathrm{ft)} \mathrm{contour}$ was extracted for Nanwalek. No DCRA elevation data existed for Anchor Point, and therefore we extracted the elevation contour of $12.2 \mathrm{~m}$ $(40 \mathrm{ft})$ from the 3-arc-second DEM of Anchor Point. Refer to the metadata that accompanies the report for more details.

To help emergency managers understand the duration of tsunami hazards after a large megathrust earthquake, we supplement the hazard maps with the time series of the modeled water level at a nearshore location in each community (white triangles in figures $8-10)$. The time series plots are shown in 

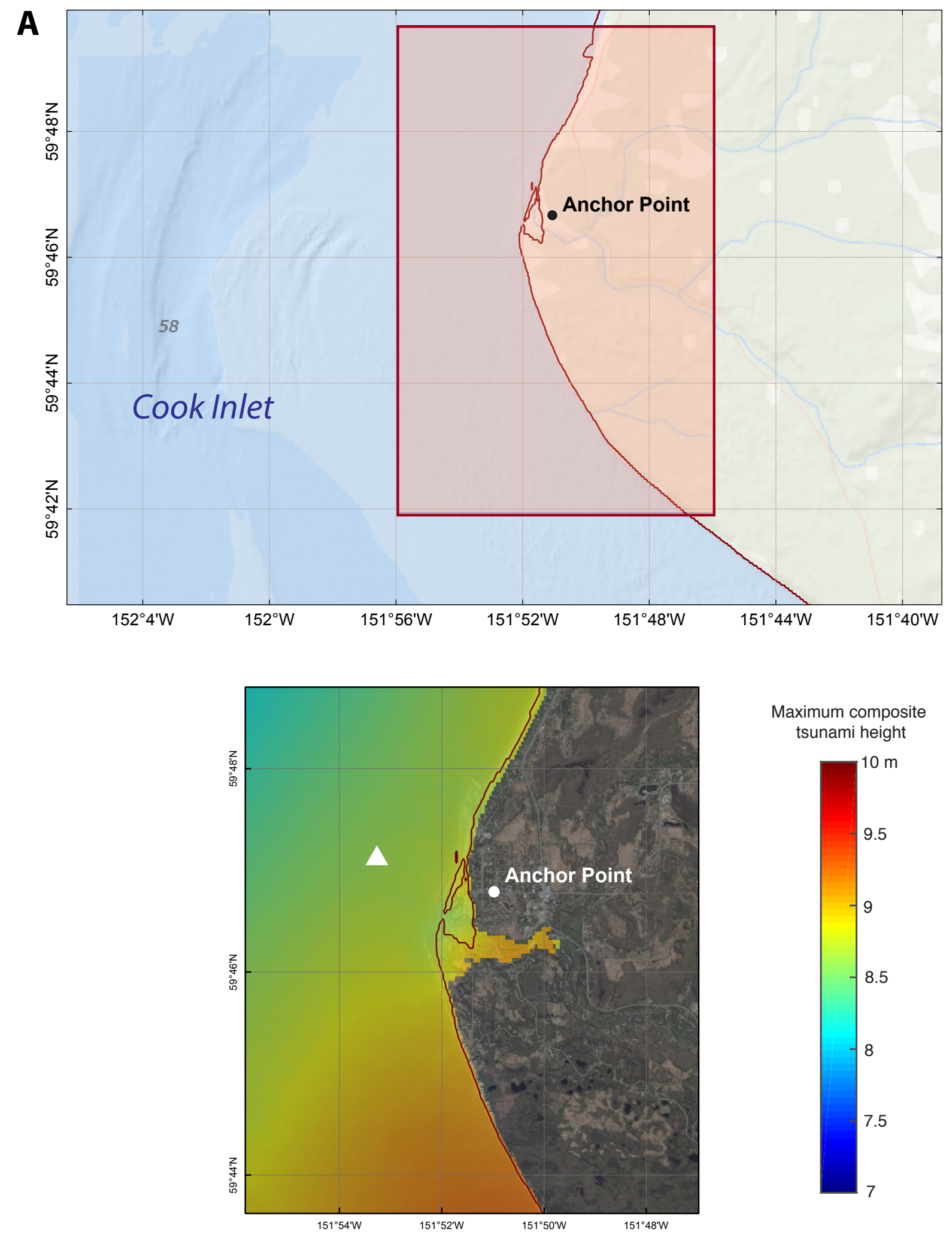

Maximum composite tsunami height

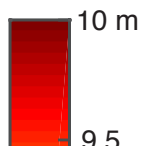

9

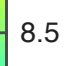

8

7.5

Figure 8. Maximum composite tsunami height at Anchor Point. The white triangle indicates the location of the time series point, and the dark red contour is the MHHW shoreline. The pink shaded rectangle in the upper map indicates the area shown in the lower map. 


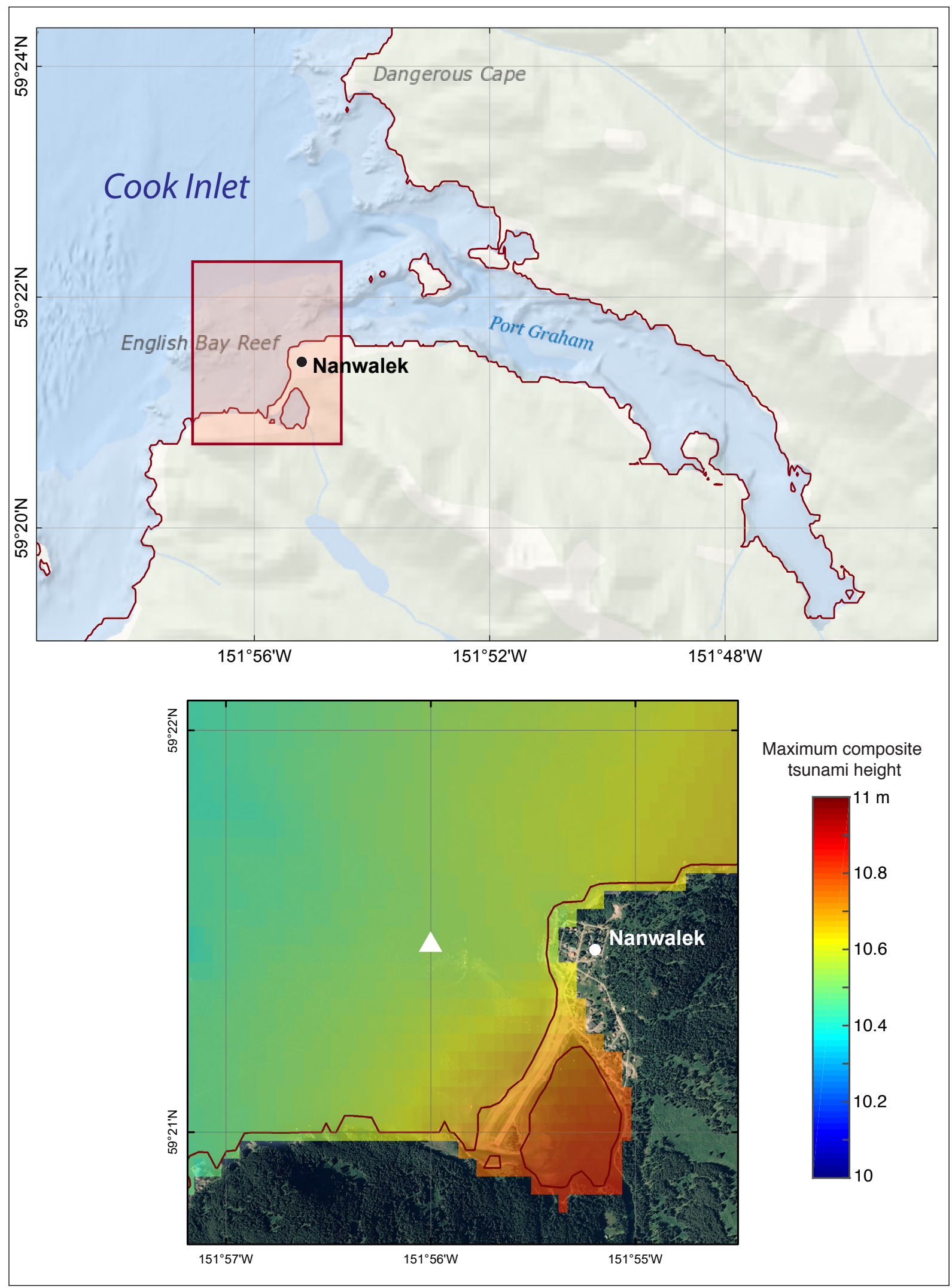

Figure 9. Maximum composite tsunami height at Nanwalek. The white triangle indicates the location of the time series point, and the dark red contour is the MHHW shoreline. The pink shaded rectangle in the upper map indicates the area shown in the lower map. 


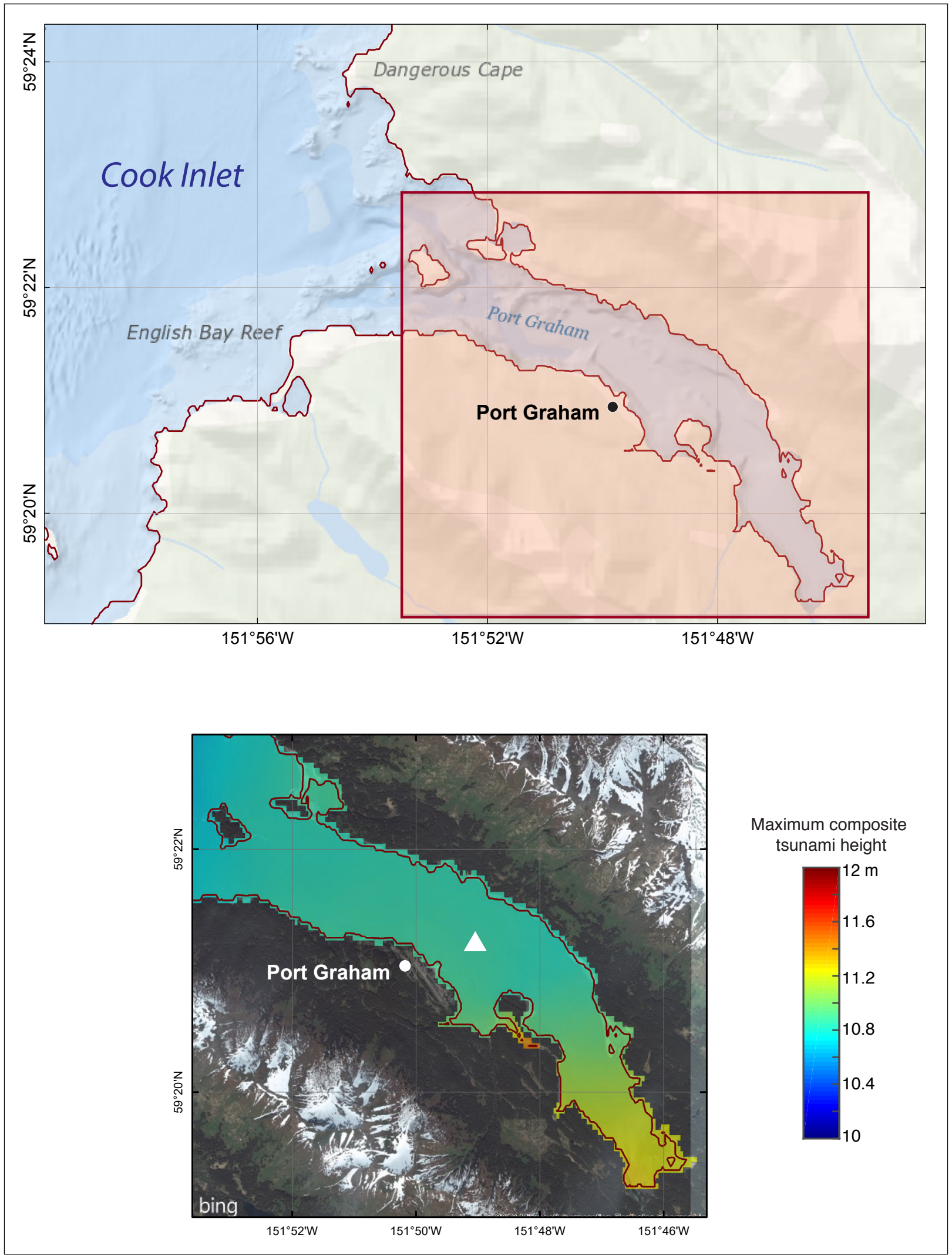

Figure 10. Maximum composite tsunami height at Port Graham. The white triangle indicates the location of the time series point, and the dark red contour is the MHHW shoreline. The pink shaded rectangle in the upper map indicates the area shown in the lower map. 

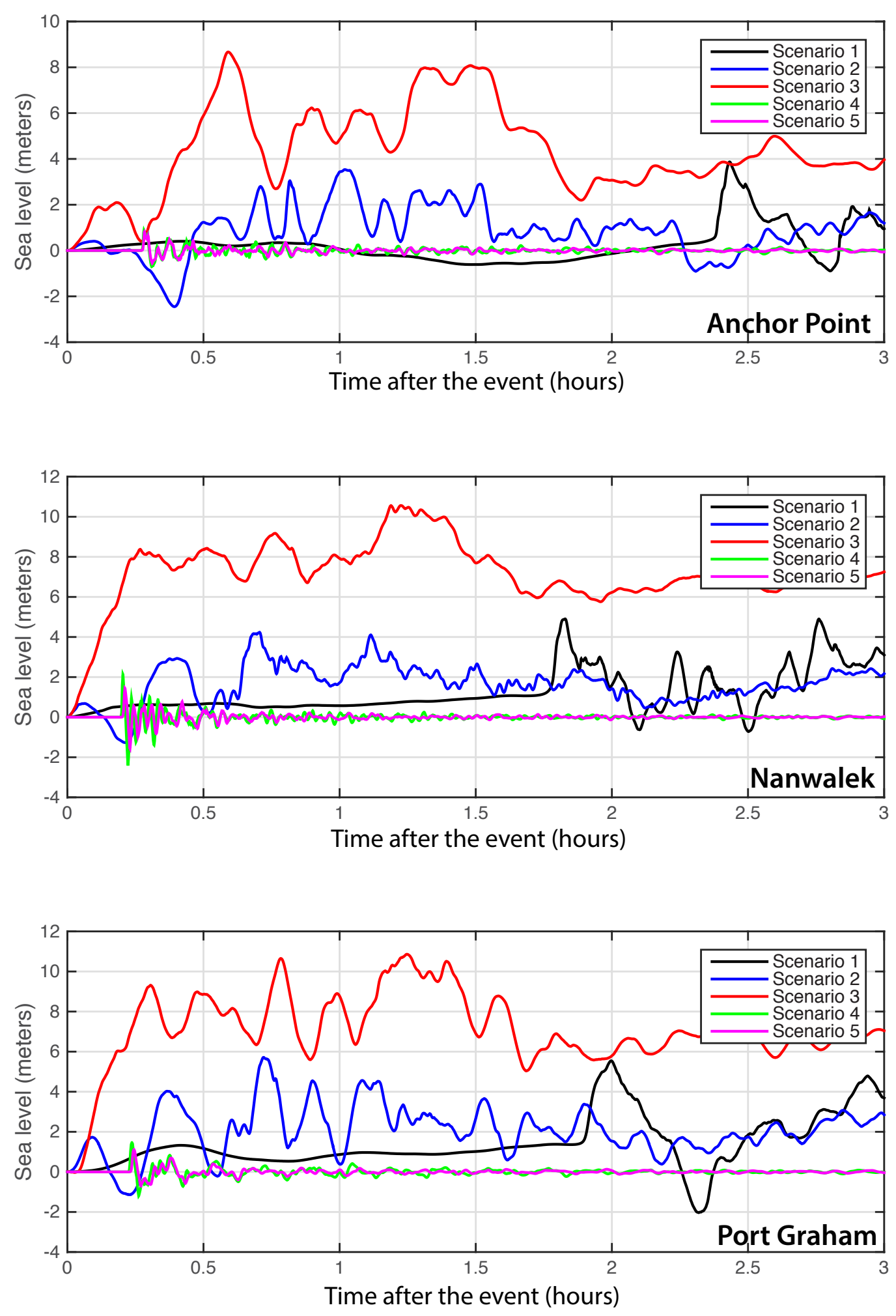

Figure 11. Time series of water level for scenarios 1-3 at Anchor Point, Nanwalek, and Port Graham, calculated at the locations shown as the white triangles in figures 8-10. 
figure 11, with zero time corresponds to the time when the earthquake or volcanic event occurs. To compare the height of arriving tsunamis for different tectonic scenarios-which result in different values of land subsidence-we use a vertical datum with a zero mark corresponding to the post-earthquake sea level. Analysis of the time series plot indicate that dangerous waves may affect the communities for more than 3 hours after the earthquake.

In addition to the time series of the simulated water levels, we have also modeled the potential permanent subsidence in the communities. The yellow line in map sheets 1-3 shows the post-earthquake MHHW shoreline after ground subsidence. Scenario 3 results in the largest amounts of subsidence in all communities (table 3). Most low-lying areas could be permanently flooded as a result of the hypothetical earthquakes considered in this report.

\section{SUMMARY}

We present the results of modeling tectonic and volcano-generated tsunamis in the region of Cook Inlet and Kenai Peninsula, and their effects on the communities of Anchor Point, Port Graham, and Nanwalek. We numerically model tsunami waves generated by local hypothetical tectonic and volcanic sources, analyze tsunami wave dynamics in the vicinity of the communities, and develop tsunami hazard maps. Specifically, we compute the composite maximum wave height from all considered scenarios and follow NTHMP guidelines to extrapolate the modeling data on land for estimation of tsunami inundation. Maximum runup heights are $12.2 \mathrm{~m}$ (40 ft)

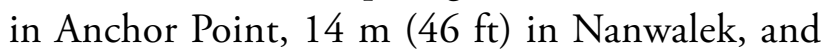
$14.9 \mathrm{~m}(49 \mathrm{ft})$ in Port Graham.

Tsunami inundation approximations shown on the tsunami hazard maps have been completed using the best information available and are believed to be accurate; however, their preparation required many assumptions. In this assessment, we estimate the potential tsunami inundation zone based on three significant earthquakes and two volcanic scenarios. Although the modeled tsunami inundation cannot be considered exhaustive, modeling results are still thought to provide a sound approximation to the potential tsunami inundation zone in the communities. Note that actual conditions during a tsunami event may vary from those considered, so the accuracy cannot be guaranteed. The limits of inundation shown should be used only as a guideline for emergency planning and response activities. Actual areas inundated will depend on specifics of the earth deformation, land construction, and tide level, and may differ from areas shown on the maps. The information on the hazard maps is intended to assist state and local agencies in planning emergency evacuation and tsunami response actions in the event of a major tsunamigenic earthquake or volcanic debris avalanche. These results are not intended for land-use regulation or building-code development.

\section{ACKNOWLEDGMENTS}

This project, which is part of the National Tsunami Hazard Mitigation Program (NTHMP), received support from the National Oceanic and Atmospheric Administration (NOAA) under Reimbursable Services Agreement ADN 952011 with the State of Alaska's Division of Homeland Security \& Emergency Management (a division of the Alaska Department of Military and Veterans Affairs). Numerical calculations for this work were supported by a grant of High Performance Computing (HPC) resources from the Arctic Region Supercomputing Center (ARSC) at the University of Alaska Fairbanks. 


\section{REFERENCES}

Alaska Department of Commerce, Community and Economic Development, Division of Community and Regional Affairs (DCCED/DCRA), 2013. dcra-cdo-dcced.opendata.arcgis.com/

Begét, J.E. and Kienle, J., 1992, Cyclic formation of debris avalanches at Mount St. Augustine Volcano, Nature, 356, p. 701-704.

DeMets, Charles, Gordon, R.C., Argus, D.F., and Stein, Seth, 1990, Current plate motions: Geophysical Journal International, v. 101, no. 2, p. 425-478.

Estabrook, C.H., Jacob, K.H., and Sykes, L.R., 1994, Body wave and surface wave analysis of large and great earthquakes along the eastern Aleutian arc, 1923-1993; Implications for future events: Journal of Geophysical Research, v. 99, no. B6, p. 11,643-11,662.

Fujii, Yushiro, Satake, Kenji, Sakai, Shin'ichi, Shinohara, Masanao, and Kanazawa, Toshihiko, 2011, Tsunami source of the 2011 off the Pacific coast of Tohoku earthquake: Earth Planets Space, v. 63, p. 815-820. terrapub. co.jp/journals/EPS/pdf/2011/6307/63070815.pdf

Geist. L.G., and Parsons, T., 2006, Probabilistic analysis of tsunami hazards: Natural Hazards, v. 37, no. 3, p. 277-314. doi.org/10.1007/s11069005-4646-z

Johnson, J.M., Tanioka, Yuichiro, Ruff, L.J., Satake, Kenji, Kanamori, Hiroo, and Sykes, L.R., 1994, The 1957 great Aleutian earthquake, Pure and Applied Geophysics, v. 142, no. 1, p. 3-28. doi.org/10.1007/BF00875966

Kanamori, Hiroo, 1970, The Alaska earthquake of 1964; Radiation of long-period surface waves and source mechanism: Journal of Geophysical Research, v. 75, no. 26, p. 5,029-5,040.

Kienle, J., Kowalik, Z., and Murty, T.S., 1987, Tsunamis generated by eruptions from Mount St. Augustine Volcano, Alaska (USA), Science, 236, p. 1,442-1,447.

Kirby, Stephen, Scholl, David, von Huene, Roland, and Wells, Ray, 2013, Alaska earthquake source for the SAFRR tsunami scenario, chapter B, in Ross, S.L., and Jones, L.M., eds., The SAFRR (Science Application for Risk Reduction)
Tsunami Scenario: U.S. Geological Survey Open-File Report 2013-1170, 40 p. pubs.usgs. gov/of/2013/1170/b/

Lander, J.F., 1996, Tsunamis affecting Alaska, 1737-1996: Boulder, CO, National Oceanic and Atmospheric Administration, National Geophysical Data Center (NGDC), Key to Geophysical Research Documentation, v. 31, 155 p.

Lim, E., Eakins, B.W., and Wigley, R., 2011, Coastal relief model of southern Alaska; Procedures, data sources and analysis: NOAA Technical Memorandum NESDIS NGDC-43, 22 p.

Lopez, A.M., and Okal, E.A., 2006, A seismological reassessment of the source of the 1946 Aleutian 'tsunami' earthquake: Geophysical Journal International, v. 165 , no. 3, p. 835-849. doi.org/10.1111/j.1365-246X.2006.02899.x

Macpherson, A.E., Nicolsky, D.J., and Suleimani, E.N., 2014, Digital elevation models of Skagway and Haines, Alaska: Procedures, data sources, and quality assessment: Alaska Division of Geological \& Geophysical Surveys Miscellaneous Publication 155, 15 p. doi.org/10.14509/29143

National Geophysical Data Center (NGDC), 2006, 2-minute Gridded Global Relief Data (ETOPO2) v2: National Geophysical Data Center (NGDC), National Oceanic and Atmospheric Administration (NOAA). doi.org/10.7289/V5J1012Q

National Geophysical Data Center/World Data Service (NGDC/WDS), continuously updated, Global historical tsunami database at NGDC, $2100 \mathrm{BC}$ to present (interactive map): National Oceanic and Atmospheric Administration (NOAA), National Geophysical Data Center (NGDC). doi.org/10.7289/V5PN93H7

National Tsunami Hazard Mapping Program (NTHMP), 2010, Guidelines and best practices for tsunami inundation modeling for evacuation planning: National Oceanic and Atmospheric Administration (NOAA), NTHMP Mapping \& Modeling Subcommittee.

2012, Proceedings and results of the 2011 NTHMP Model Benchmarking Workshop: Boulder, CO, U.S. Department of Commercel NOAA/NTHMP, NOAA Special Report, 436 p. nthmp.tsunami.gov 
Nicolsky, D.J., Suleimani, E.N., Combellick, R.A., and Hansen, R.A., 2011a, Tsunami inundation maps of Whittier and western Passage Canal, Alaska: Alaska Division of Geological \& Geophysical Surveys Report of Investigation 2011-7, 65 p. doi.org/10.14509/23244

Nicolsky, D.J., Suleimani, E.N., and Hansen, R.A., 2011 b, Validation and verification of a numerical model for tsunami propagation and runup: PUre and Applied Geophysics, v. 168, p. 1,199-1,222. doi.org/10.1007/s00024-010-0231-9

Nicolsky, D.J., Suleimani, E.N., Haeussler, P.J., Ryan, H.F., Koehler, R.D., Combellick, R.A., and Hansen, R.A., 2013, Tsunami inundation maps of Port Valdez, Alaska: Alaska Division of Geological \& Geophysical Surveys Report of Investigation 2013-1, 77 p., 1 sheet, scale 1:12,500. doi.org/10.14509/25055

Nicolsky, D.J., Suleimani, E.N., and Koehler, R.D., 2014, Tsunami inundation maps of Cordova and Tatitlek, Alaska: Alaska Division of Geological \& Geophysical Surveys Report of Investigation 2014-1, 49 p. doi.org/10.14509/27241

Plafker, George, 1969, Tectonics of the March 27, 1964, Alaska earthquake: U.S. Geological Survey Professional Paper 543-I, 74 p.

Ross, S.L., Jones, L.M., Miller, Kevin, P., K.A., Wein, A., Wilson, Ri.I., Bahng, B., Barberopoulou, A., Borrero, J.C., Brosnan, D.M., Bwarie, J.T., Geist, E.L., Johnson, L.A., Kirby, S.H., Knight, W.R., Long, K., Lynett, P., Mortensen, C.E., Nicolsky, D.J., Perry, S.C., Plumlee, G.S., Real, C.R., Ryan, K., Suleimani, E., Thio, H., Titov, V.V., Whitmore, P.M. and Wood, N.J., 2013, SAFRR (Science Application for Risk Reduction) Tsunami Scenario-Chapter A, Executive Summary and Introduction, in Ross, S.L., and Jones, L.M., eds., The SAFRR Tsunami Scenario: U.S. Geological Survey Open-File Report 2013-1170, p. 1-17. pubs.usgs.gov/of/2013/1170/

Shao, Guangfu, Li, Xiangyu, Ji, Chen, and Maeda, Takahiro, 2011, Focal mechanism and slip history of $2011 \mathrm{M}_{\mathrm{W}} 9.1$ off the Pacific coast of Tohoku earthquake, constrained with teleseismic body and surface waves: Earth Planets Space, v. 63, no. 7, p. 559-564. doi.org/10.5047/eps.2011.06.028 Suleimani, E.N., Nicolsky, D.J., West, D.A., Combellick, R.A., and Hansen, R.A., 2010, Tsunami inundation maps of Seward and Northern Resurrection Bay, Alaska: Alaska Division of Geological \& Geophysical Surveys Report of Investigation 2010-1, 47 p., 3 sheets, scale 1:12,500. doi.org/10.14509/21001

Suleimani, E.N., Nicolsky, D.J., and Koehler, R.D., 2013, Tsunami inundation maps of Sitka, Alaska: Alaska Division of Geological \& Geophysical Surveys Report of Investigation 2013-3, 76 p., 1 sheet, scale 1:250,000. doi.org/10.14509/26671

Suleimani, E.N., Nicolsky, D.J., and Koehler, R.D., 2015, Tsunami inundation maps of Elfin Cove, Gustavus and Hoonah, Alaska: Alaska Division of Geological \& Geophysical Surveys Report of Investigation 2015-1, 79 p. doi.org/10.14509/29404

Suleimani, E.N., Nicolsky, D.J., Koehler, R.D., and Salisbury, J.B., 2018, Regional tsunami hazard assessment for Andreanof Islands, Alaska: Alaska Division of Geological \& Geophysical Surveys Report of Investigation 2017-2, 19 p., 2 sheets. doi.org/10.14509/29704

Synolakis, C.E., Bernard, E.N., Titov, V.V., Kânoğlu, U., and González, F.I., 2007, Standards, criteria, and procedures for NOAA evaluation of tsunami numerical models: Seattle, WA, NOAA/Pacific Marine Environmental Laboratory, Technical Memorandum OAR PMEL-135, 55 p.

Waitt, R.B., Begét, J.E and Kienle, J., 1996, Provisional geologic map of Augustine Volcano, Alaska, U.S. Geological Survey Open-File Report OF-96-0516.

Waythomas, C.F., Watts, P., and J. S. Walder, 2006, Numerical simulation of tsunami generation by cold volcanic mass flows at Augustine Volcano, Alaska, Natural Hazards and Earth System Science, 6 (5), p. 671-685.

Wu, F.T., and Kanamori, Hiroo, 1973, Source mechanism of February 4, 1965, Rat Island earthquake: Journal of Geophysical Research, v. 78 , no. 26, p. 6,082-6,092. 